СТАНОВЛЕННЯ МЕРЕЖІ УСТАНОВ ЛІКВІДАЦІЇ НЕПИСЬМЕННОСТІ ДЛЯ НАЦІОНАЛЬНИХ МЕНШИН НА ТЕРИТОРІЇ ПІВНІЧНО-СХІДНОЇ УКРАЇНИ У 20-Х РОКАХ ХХ СТОЛІТТЯ

\title{
ESTABLISHMENT OF THE NETWORK OF INSTITUTIONS FOR THE ELIMINATION OF LITERACY FOR NATIONAL MINORITIES IN NORTH-EASTERN UKRAINE IN THE 20-S YEARS OF THE XX CENTURY
}

у статті за результатами дослідження
архівних матеріалів здійснений аналіз
формування мережі установ ліквідації
неписьменності для національних меншин
у Північно-Східній україні у 20-х роках
ХХ століття. З'ясовані соціально-політичні
умови становлення мережі установ ліквіда-
ції неписьменності для національних мен-
шин. Визначені основні чинники, що зумов-
лювали розвиток установ зазначеного типу
(потреба в освічених громадянах для розви-
тку промисловості та індустріалізації, вико-
ристання письменних громадян як об'єкта
і суб'єкта ідеологічного впливу, необхідність
об'єднання населення під спільними соціаліс-
тичними гаслами).

Розглянуто прочеси формування нормативно-правової бази, створення керівних установ та організацію заходів із виявлення неписьменних. Доведено, що управлінська мережа установ ліквідації неписьменності для національних меншин об'єднувала як державні, так і громадські органи. Висвіт лено настановчо-організаційні заходи щодо забезпечення діяльності установ ліквідації неписьменності національних меншин на території Північно-Східної України. Проаналізовано основні заходи щодо популяризації боротьби з неписьменністю як на державному, так і на місцевому рівні.

Схарактеризовано основні типи установ ліквідації неписьменності національних меншин (школи ліквідації неписьменності, школи для малописьменних та вечірні робітничі школи II ступеня). Виявлено та проаналізовано механізм укрупнення установ ліквідації неписьменності національних меншин на території Північно-Східної України. За допомогою хронологічного та системноструктурного методів розглянуто динаміку поширення установ ліквідації неписьменності та схарактеризовано чинники, що ії зумовлювали.

Ключові слова: національні меншини, заклади освіти національних меншин, ліквідація неписьменності, установи ліквідації неписьменності, заклади політосвіти, уста- нови ліквідації неписьменності національних меншин.

According to the results of a study of archival materials, the article analyzes the formation of the network of Institutions for the Elimination of Literacy for national minorities in North-Eastern Ukraine in the 20-s of the XX century.

The socio-political conditions for the establishment of a network of literacy institutions for national minorities are clarified. The main factors that determined the development of institutions of this type (a lack of educated citizens for the development of industry and industrialization, the use of competent citizens as an object and subject of ideological influence, the need to unite the population under common socialist slogans) are determined.

The processes of forming the regulatory framework, the establishment of governing institutions and the organization of measures to identify illiterates are discovered. It has been proven that the management network of literacy institutions for national minorities united both state and public bodies. Institutional organizational measures to ensure the activities of institutions for the elimination of illiteracy of national minorities in the territory of North-Eastern Ukraine are highlighted. The main measures to popularize the fight against illiteracy both at the state and local levels are analyzed.

The main types of institutions for the elimination of illiteracy of national minorities (schools for the elimination of illiteracy, schools for the illiterate and evening working schools of the second degree) are characterized. The mechanism of enlargement of the institutions for the elimination of illiteracy of national minorities in the territory of North-Eastern Ukraine is identified and analyzed. Using the chronological and system-structural methods, the dynamics of literacy institutions spread has been examined and the factors have been specified.

Key words: national minorities, educational institutions of national minorities, literacy, literacy institutions, political education institutions, literacy institutions for national minorities.
Постановка проблеми у загальному вигляді. Україна, ратифікувавши цілу низку міжнародних правозахисних документів, імплементувала міжнародні стандарти захисту прав національних меншин та взяла на себе відповідальність за створення належних умов для розвитку етнічної, культурної, мовної та релігійної самобутності кожної особи, яка належить до національних меншин.

Побудова раціональної освітньої політики нашої країни стосовно національних меншин та корінних народів має як ґрунтуватися на нормах міжнародного права, так і спиратися на об'єктивні фракти власного історичного досвіду. Це, своєю чергою, вимагає ретельних історико-педагогічних досліджень освіти національних меншин як усієї України, так і окремих ії̈ регіонів.

Аналіз останніх досліджень і публікацій. Історико-педагогічному дослідженню ліквідації неписьменності на території УСРР присвятили свої праці А.М. Журба, О.М. Мовчан, І.С. Зозуляк, В.В. Козир, О.М. Бойко, М.П. Олійник. Організація та проведення ліквідації неписьменності серед національних меншин висвітлені в роботах О.С. Гончарової, Л.Д. Якубової, О.О. Войналович, 
О.П. Данильченко, О.О. Слесаренко, Л.В. Гуцало та ін.

Виділення не вирішених раніше частин загальної проблеми. 3 огляду на регіональні особливості культурно-освітніх установ національних меншин, комплексного дослідження потребує проблема становлення мережі установ ліквідації неписьменності національних меншин на території Північно-Східної України.

Мета статті - з'ясувати організаційні особливості формування мережі установ ліквідації неписьменності для національних меншин Північно-Східної України у 20-х роках XX століття.

Виклад основного матеріалу. Невід'ємною частиною проголошеного радянською владою курсу на соціалізм було досягнення належного культурно-освітнього рівня народу. В країні, де $68,1 \%$ населення було неписьменним [1, с. 16], першочерговим завданням визначалася ліквідація неписьменності.

Для радянського уряду письменність населення була головним засобом політичного впливу й виховання. Ідеолог та керманич РКП (б) В. Ленін вказував на те, що без письменності не можливе політичне будівництво країни: «Неграмотна людина поза політикою <...> Сліпа людина теж може орієнтуватися в навколишньому середовищі, але дуже погано; і неграмотна людина може бути непоганим радянським громадянином, але дуже скаліченим» [2, с. 10].

У травні 1921 року в УССР із метою надання населенню «можливості свідомої участі в політичному житті» було прийнято декрет «Про ліквідацію неписьменності». Цей документ копіював зміст російського, прийнятого у грудні 1919 року, і, згідно 3 ним, усе населення віком від восьми до п'ятдесяти років, яке не вміло писати та читати, зобов'язувалося вчити грамоту рідної чи російської мови за бажанням [3]. Положення декрету передбачали заходи з ліквідації неписьменності на загальнодержавному рівні із залученням усіх профрспілкових, кооперативних, партійних організацій республіки.

Перший всеросійський з'їзд із ліквідації неписьменності (1922) проголосив першочерговим завданням навчання грамоти працівників промислових підприємств, колгоспів, членів профспілок віком від вісімнадцяти до тридцяти років. Постановою Другого всеросійського з'їзду 3 ліквідації неписьменності проголошувалося «з повним усвідомленням всієї важливості та відповідальності перед взятим на себе зобов'язанням ліквідувати неграмотність серед населення СРСР до десятиліття Жовтневої революції» [4]. У такий спосіб була зроблена спроба штучного фрорсування темпів ліквідації неграмотності, а процес добровільного долучення народу до знань перетворився на політичне завдання, яке було поставлене перед радянською владою.
3 метою координації та контролю роботи 3 ліквідації неписьменності при НКО УССР була створена Всеукраїнська надзвичайна комісія з боротьби із неписьменністю (ВУНКЛН). До ссрери ії діяльності входило: «керівництво всією роботою з ліквідації неписьменності і малописьменності на території УССР; створення мережі лікнепів (установ із ліквідації неписьменності) і шкіл для малописьменних; керівництво підготовкою і перепідготовкою працівників, які займалися ліквідацією неписьменності; видання програм, букварів та книг для малописьменних» [5]. У 1923 році постановою ВУЦВК для допомоги Народному комісаріату освіти в організації ліквідації неписьменності було створене Всеукраїнське товариство «Геть неписьменність» на чолі з Г. Петровським [5]. Товариство та його місцеві осередки займалися агітаційною, організаційною та фрінансовою підтримкою установ ліквідації неписьменності.

На Всеукраїнській нараді завідувачів губернських відділів народної освіти питання організації установ ліквідації неписьменності серед національних меншин було одним із головних. У доповіді заступника голови ради національних меншин при народному комісаріаті освіти Д. Маца наголошувалося: «Основна наша задача у ссрері ліквідації неписьменності зводиться до того, щоб через друковане слово отримати могутню зброю політичного впливу на робітничі маси, а підняття їх культурного духу можливо буде досягнути, якщо неграмотність ліквідується рідною мовою» [6, арк. 31]. На важливість організації закладів ліквідації неписьменності серед національних меншин неодноразово звертали увагу очільники національних відділів. Так, завідувач Харківської вірменської секції необхідність відкриття школи грамоти для дорослих пояснював таким чином: «Вірменське населення не лише не знає російської мови, вони не знають навіть своєї рідної мови, і більшість вірмен прагнуть ознайомитися як з російською, так і з вірменською мовами» [7, арк. 82]. Отже, з огляду на значення вивчення рідної мови та гарантоване право усіх національностей навчатися нею процес всесоюзної ліквідації неписьменності охопив і представників національних меншин.

При всіх місцевих відділах народної освіти були створені місцеві надзвичайні комісії для боротьби із неписьменністю. На Харківщині губернська комісія з ліквідації неписьменності була створена наприкінці липня 1920 року. До цього часу робота 3 ліквідації неграмотності велася шкільною секцією політпросвіти. До складу Харківської губернської комісії з ліквідації неписьменності увійшли представники від губернського відділу народної освіти, профросвіти, парткому та виконкому.

Першим завданням губернської комісії стала організація зимової кампанії з ліквідації неписьменності. Для ії вирішення була організована 
методологічна комісія з розробки методичних вказівок та програм. Процес проведення зимової кампанії вимагав належного дидактичного й канцелярського забезпечення, з метою отримання якого у вересні до Києва була відряджена голова Харківської комісії тов. Подгорненськая [8, арк. 16]. Своєю чергою, для утримання повітових відділів із ліквідації неграмотності губкомісія отримувала забезпечення з Москви та Всеукраїнської комісії 3 ліквідації неграмотності [там само].

Після завершення організаційних питань Харківська комісія 3 ліквідації неписьменності перейшла до вирішення одного 3 основних завдань кампанії ліквідації неписьменності (лікнепу) - агітації та популяризації просвітньої роботи серед населення, в тому числі і серед національних меншин. 3 огляду на всю важливість цього завдання було прийнято рішення «поставити його в рамки бойової задачі дня» [8, арк. 15].

Успішній організації кампанії 3 ліквідації неписьменності національних меншин перешкоджала зайнятість робітників на виробництві. 3 метою покращення відвідуваності пунктів ліквідації неписьменності Харківська комісія з ліквідації неписьменності низкою клопотань домоглася підписання постанови щодо вивільнення для працюючих двох годин на навчання. Окрім того, години, відведені на навчання, оплачувалися згідно з фактичним заробітком. За наявності на підприємстві великої кількості неписьменних групові заняття організовувалися за згодою адміністрації через завкоми та фрабкоми таким чином, щоб число робітників, які одночасно навчалися на курсах, не перевищувало десять відсотків від загальної кількості працівників підприємства. 3 метою популяризації лікпунтів Харківською губернською комісією було запропоновано заохочення учнів, що полягало в преміюванні осіб, які закінчили навчання в них [8, арк. 16]. Усі ці заходи сприяли підвищенню популярності лікнепів серед населення.

У результаті налагодження роботи центральної та губернських комісій із ліквідації неписьменності число установ стабільно зростало. Так, за даними Ради національних меншин, станом на 1924-1925 роки в Україні діяло 355 єврейських, 163 польських та 89 німецьких лікпунтів та шкіл для малописьменних [6, арк. 26]. Уже у 1925-1926 роках в УСРР фрункціонувало 930 установ із ліквідації неписьменності, з них: 507 єврейських, 163 німецькі, 175 польських, 35 болгарських, 46 татарських, 2 латвійські, 1 вірменська та 1 ассирійська [там само]. Позитивна динаміка лікнепів для національних меншин була зазначена в «Доповіді уряду УСРР до Президіуму ради національностей ЦВК IV скликання про стан та характер роботи серед національних меншин у республіці». У документі підкреслювалося, щоб «в справі ліквідації неписьменності національних меншин вико- нана значна робота та розгорнута велика мережа відповідних установ» [8, арк. 85].

Тенденція зростання кількості закладів лікнепу була притаманна і північно-східному регіону республіки. Зокрема у 1924-1925 роках Харківську округу обслуговувало 40 лікпунктів. Через їх мережу навчання пройшли 22274 людини. У місті Харків фрункціонувало 30 лікпунктів та 20 шкіл для малограмотних. Випускниками цих закладів стали 1474 неписьменних та 2304 малописьменних [9, арк. 84]. Станом на 1927 рік із загальної кількості закладів ліквідації неписьменності Харківської губернії 9 груп та 200 учнів становили національні меншини [10, арк. 8]. У резолюції по роботі з ліквідації неписьменності серед національних меншин Харківщини наголошувалося на широкому охопленні працюючих різних національностей мережею лікнепу міста (7 національностей) та частково округу (польські школи в Мерефрі та Допрі) [11, арк. 9].

Стрімке поширення установ ліквідації неписьменності серед національних меншин спостерігалася і на Чернігівщині. Так, якщо на 1924 рік у губернії діяли лише два лікпунти для єврейського населення [12, арк. 25], то в 1925 році були відкриті три школи ліквідації неписьменності в Чернігові, дві - в Сновську та по одній - у Борзні, Конотопі, Городні, Остері та Березному [13, арк. 15]. Процес зростання установ ліквідації неписьменності національних меншин на території ПівнічноСхідної України спостерігався й надалі.

Найчисельнішим типом закладів із ліквідації неписьменності серед національних меншин були лікпунти, термін навчання в яких тривав до п'яти місяців. Основні завдання організації пунктів ліквідації неписьменності полягали в оволодінні грамотою за короткий термін із найменшою затратою часу, сил, людських та матеріальних ресурсів, залученні якомога більшої кількості неписьменних та фрормування стійкої мотивації до навчання, прищепленні інтересу до знань, виробленні прагнення до самоосвіти, фрормуванні комуністичної свідомості національних меншин через наповнення навчального матеріалу політичним змістом.

3 кінця 20-х років XX століття 3 огляду на розпорошеність та малу чисельність лікпунтів національних меншин поширеними стають випадки їх укрупнення. Так, у 1929 році на Харківщині було прийнято рішення про об'єднання лікнепів регіону та створення єдиної бази ліквідації неписьменності для національних меншин. Вона охоплювала такі національності: одна група корейців на 14 осіб; три групи китайців на 52 особи; дві групи татар на 36 учнів; шість груп вірмен на 120 осіб; одна група персів на 10 осіб; одна група грузинів на 7 учнів; одна група ассирійців на 18 учнів; дві групи поляків на 25 осіб; дві групи циган на 10 чоловік; шість груп єврейського населення на 100 осіб. При базі працювало 18 працівників: 14 педагогів 
(на вісім ставок), 1 методист та завідувач базою [14, арк. 12]. Варто зазначити, що особи не всіх національностей мали змогу вчитися грамоти рідною мовою. Через брак педагогів відповідних національних меншин лише євреї, поляки, вірмени та татари навчалися мовою своєї національності, решта вчилася російською мовою.

Незважаючи на труднощі, за 1929-1930 рік випускниками Харківської бази ліквідації неписьменності стало 411 осіб різних національностей. Досягненням роботи можна вважати те, що працівники установи домоглися організації груп робітфраку з числа випускників курсів, що дало змогу останнім продовжити навчання та оволодіти робітничими спеціальностями, забезпечивши, таким чином, наступність навчання. Зі схожою метою в містах Сосниці та Конотопі були організовані вечірні професійні курси для єврейського населення, що належали до вечірніх робітничих шкіл II ступеня. Їхня головна мета полягала в поєднанні ліквідації неписьменності та професійної підготовки єврейських підлітків, місцевих робітників та ремісників старшого шкільного віку, які не мали змогу відвідувати школу.

ще одним типом установ із ліквідації неписьменності на території Північно-Східної України були вечірні школи для малограмотних. Зазвичай такі школи призначалися для партійних громадян, яких зараховували за результатами політперевірки до першої групи. Проте до навчання в таких закладах допускалися й безпартійні працівники, вони становили до 40\% усіх учнів. Комплект таких шкіл передбачав 200 учнів та 12 учителів. За необхідності дозволялося розбивати учнів на кілька шкіл по 30-35 чоловік. Термін навчання в школах для малограмотних становив шість місяців. Заняття проходили ввечері тричі на тиждень по 2-3 години. Для навчання вечірні школи використовували приміщення трудових шкіл, радпартшкіл, клубів, і в такий спосіб витрати на їх утримання обмежувалися лише фрінансуванням навчальної частини [15, арк. 91]. Отже, організаційними фрормами ліквідації неписьменності серед національних меншин були курси ліквідації неписьменності, школи для малограмотних та вечірні школи підвищеного типу.

Висновки. Таким чином, за результатом проведеного дослідження встановлено, що для ліквідації масової неписьменності та з метою політичного управління населенням країни на початку 20-х років в УСРР були створені спеціальні освітні установи 3 ліквідації неписьменності. Гарантоване державою право навчатися рідною мовою сприяло формуванню мережі закладів із ліквідації неграмотності для національних меншин. Ці установи ставили за мету в найкоротший термін навчити грамоти та надавали змогу максимальній кількості населення отримати загальні освітні знання мовою національних меншин.

Визначено поширені типи закладів ліквідації неписьменності серед національних меншин у Північно-Східній Україні. 3'ясовано, що з середини 20-х років на території Північно-Східної України простежується щорічна позитивна динаміка збільшення установ ліквідації неписьменності та кількості грамотного населення серед національних меншин. Як результат упроваджених державою заходів до початку 30-х років на території Північно-Східної України представники майже всіх національних меншин (у тому числі й малочисельних) отримали змогу навчатися в установах ліквідації неписьменності, що сприяло підвищенню рівня освіченості національного населення регіону та забезпечило можливість його подальшого навчання й культурного розвитку.

\section{БІБЛІОГРАФІЧНИЙ СПИСОК:}

1. Народна освіта і культура в Українській РСР. Статистичний збірник. Київ : Статистика, 1973.

2. В помощь организатору народного просвещения. Сборник статей по вопросам инспектирования и руководства просветительной работой / И. Перель (ред.). Москва : Работник просвещения, 1926.

3. Декрет о ликвидации неграмотности. URL: http://www.rusarchives.ru/projects/statehood/08-41dekret-bezgramotnost-1918.shtml

4. Педагогические сочинения. Том 9: Ликвидация неграмотности и малограмотности; Школы взрослых; Самообразование / Н.К. Гончарова, И.А. Каирова, И.В. Чувашева (ред.). Москва : Изд-во АПН, 1960.

5. Бондарчук П.М. Всеукраїнська надзвичайна комісія по боротьбі 3 неписьменністю (ВУНКЛН). Енциклопедія історії України: Т. 1: А-В. Київ : вид-во «Наукова думка», 2003.

6. Центральний державний архів вищих органів влади та управління України. Ф. 413. Оп. 1. Спр. 381.

7. Державний архів Харківської області України. Ф. Р-820. Оп. 1. Спр. 158.

8. Державний архів Харківської області України. Ф. Р-820. Оп. 1. Спр. 24.

9. Державний архів Харківської області України. Ф. Р-845. Оп. 2. Спр. 365

10. Державний архів Харківської області України. Ф. Р-845. Оп. 2. Спр. 613.

11. Державний архів Харківської області України. Ф. Р-845. Оп. 3. Спр. 1970.

12. Державний архів Чернігівської області України. Ф. Р-593. Оп. 3. Спр. 74.

13. Державний архів Чернігівської області України. Ф. Р-593. Оп. 3. Спр. 79.

14. Державний архів Харківської області України. Ф. Р-408. Оп. 4. Спр. 2637.

15. Державний архів Сумської області України. Ф. Р-2310. Оп. 1. Спр. 314. 